\title{
Were There Commercial Communications between Prehistoric Harappans and African Populations?
}

\author{
Kenneth A. R. Kennedy ${ }^{1,2^{*}}$, Gregory L. Possehl ${ }^{3}$ \\ ${ }^{1}$ Department of Ecology and Evolutionary Biology, Cornell University, New York, USA \\ ${ }^{2}$ Department of Anthropology, and Asian Studies, Cornell University, New York, USA \\ ${ }^{3}$ Department of Anthropology, University of Pennsylvania, Philadelphia, USA \\ Email: "kak10@cornell.edu
}

Received July $4^{\text {th }}$, 2012; revised August 20 $0^{\text {th }}$, 2012; accepted September $4^{\text {th }}$, 2012

\begin{abstract}
This paper is an historical and scientific evaluation of Western archaeologists' theories concerning ancient population movements and commercial contacts between the prehistoric Harappans and African populations during the Indus Age (2500-1900 BC). In this context the human skeletal remains and artifacts from Harappa and Mohenjodaro are relevant. An urn-burial from the Indus river site of Chanhu-daro has an important bearing upon this subject. The scientific aspect of this study is the provision of hitherto unascertained data to palaeoanthropologists anaylsing the skeletal and dental biology of prehistoric populations of South Asia.
\end{abstract}

Keywords: Prehistoric Harappans

\section{Introduction}

Chanhu-daro is an archaeological site of the Indus Civilization (2500-1900 BC) situated in the lower Indus valley of Pakistan near the east bank of the river and some $643.6 \mathrm{~km}$ from Mohenjo-daro. The circumstances of the burial of a human cranium in a pottery jar are unique in the record of Indus Age disposal of the dead. Excavated in the field session of 1935-1936 under the supervision of E. J. H. Mackay (1932), the cranium was sent to the American biological anthropologists, Drs. T. Wingate Todd (1943), W. M. Krogman, and W. H. Sassaman (1943). Their analysis of the specimen at laboratories at Case Western Reserve University and the University of Chicago led them to conclude that it possessed some morphometric features suggestive of East African rather than South Asian ancestral origins for the Chanhu-daro skull. Further implications involving the skull and its archaeological associations pertain to economic trade contacts between the Indus valley within the "Middle Asian Interaction Sphere" and Africa, e.g. millets and sorghum, crops encountered in prehistoric archaeological contexts in these parts of the world. The apparent East African physical features portrayed in the "dancing girl" statuette from the Indus urban site of Mohenjodaro are discussed.

\section{The Chanhu-Daro Cranium}

A human cranium was discovered during the 1935-1936 season of excavation at Chanhu-daro, a site in the Lower Indus Valley of modern Pakistan. This cranium was associated with a structure of the Indus Age, or Harappan Civilization (Figure 1) and is assessed by the present authors with respect to two hypotheses hitherto unproposed by archaeologists and palaeoanthropologists: 1) The Chanhu-daro burial is a unique funerary practice of the Indus Civilization, unencountered at other Indus sites; 2) the cranium's phenotypic features are outside the

\footnotetext{
"Corresponding author.
}

range of morphological variation present in the macropopulations of the Indus Civilization, but fit closely with those of individuals of East African ancestry, possibly Nubian or Ethiopian. Our interpretations of these data support these hypotheses and others relevant to broader questions: How did the people of this culture dispose of their dead? What was the degree of biological and demographic diversity of the Indus peoples? And what was the nature and extent of contacts of the ancient inhabitants of the Indus Civilization, and Chanhu-daro specifically, with populations living beyond the Indus Valley? Following the first excavations at the site of Harappa in the Punjab in 1920 and at Mohenjo-daro in Sind in 1922 under the general supervision of Sir John Marshall (1876-1958) (1931), General-Director of the Archaeological Survey of India, there was keen interest in investigating other Indus sites. Nani Gopal Majumdar (1897-1938) (1934) explored sites in Sind. Through the efforts of W. Norman Brown (1892-1975), Professor of Sanskrit at the University of Pennsylvania, the first American archaeological expedition to British India was organized. Supervision was under the Field Director, Ernest John Henry Mackay (1880-1943) (1930-1934, 1936, 1943). This excavation was funded by the Museum of Fine Arts in Boston (Possehl, 1999).

Chanhu-daro is a settlement marked by three low mounds covering approximately five hectares in Nawabshah District of Sind, Pakistan (Figure 2). It lies some $19.3 \mathrm{~km}$ from the eastern bank of the Indus River, $640 \mathrm{~km}$ south-southeast of Mohenjo-daro (Figure 3). Alluvium covers the lower parts of the mounds.

Mackay (1943) established four cultural levels at Chanhudaro:

Occupation 4 Jhangar (Iron Age?)

Occupation 3 Trihni (Bronze Age or Iron Age?)

Occupation 2 Jhukar (Post-urban Harappan)

Occupation 1 Harappa

Stuwart Piggott (1910-1996) (1950) revised this scheme as 


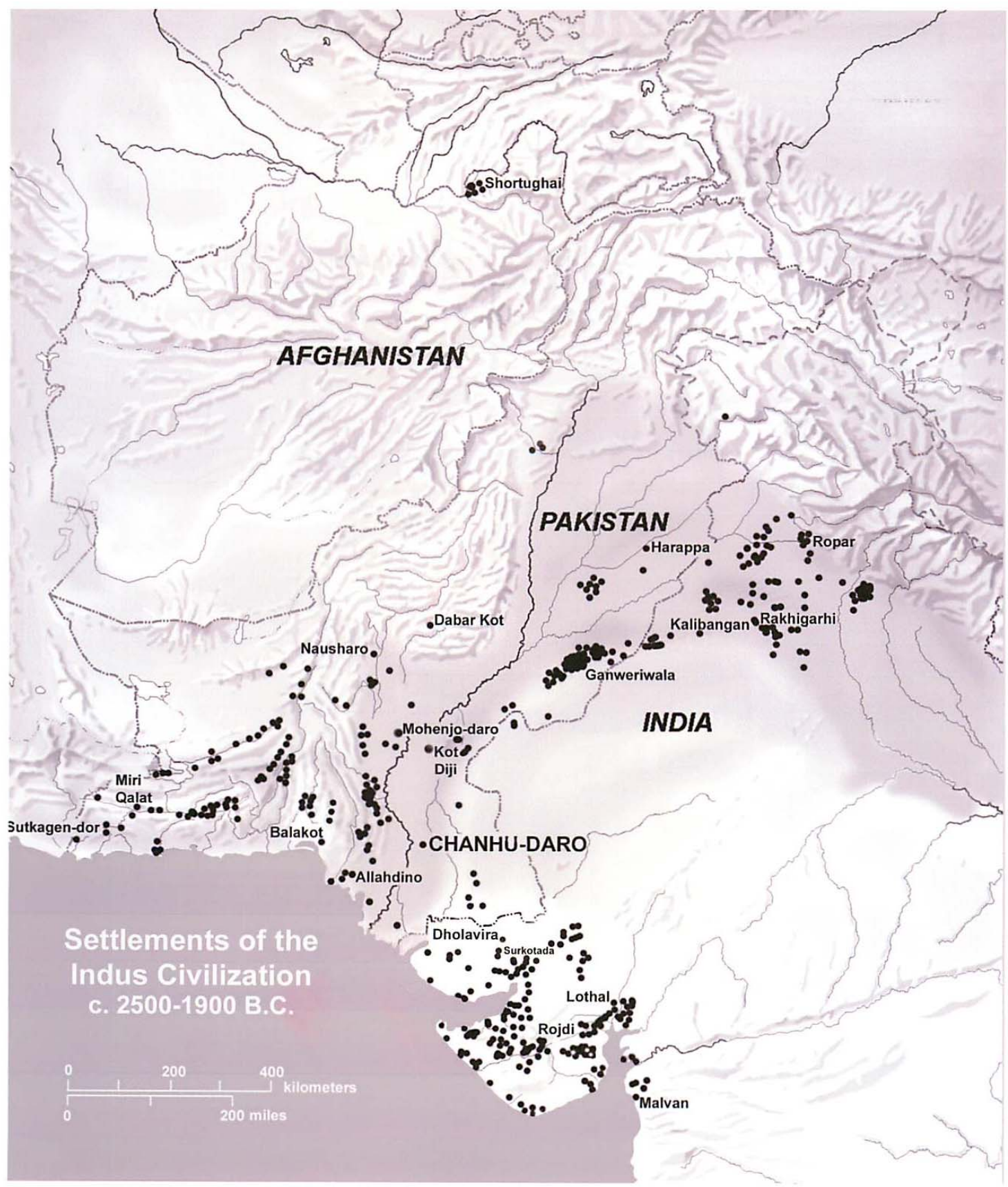

Figure 1.

Settlements of the Indus Civilization c, 2500-1900 BC.

follows:

Period III Jhangar

Period II Jhukar

Period I a-c Mature Harappan

The occupation that Mackay exposed most fully is his Harappa II, of Stuwart Piggott's (1910-1996). (1946, 1950) Period Ic, best preserved on Mound II. Here he found a "typical” Mature Sindhi Harappan settlement. Chanhu-daro's citizens used baked bricks for many buildings, had paved floors and a drainage system. Some buildings were grouped along a wide street that ran north-west to south-east (different from
Mohenjo-daro's city plan) that appears to have been cut by at least one thoroughfare coming in at a right angle. This attention to town planning was not seen in the uppermost Mature Harappan levels (Mackay, 1943). Figurines and toys of copper-bronze and terra cotta were recovered along with an abundance of chalcedony and carnelian beads, shell ornaments, ceramics and faience work. These manufactured goods suggest that Chanhudaro was an important craft center with trade connections with other Harappan cities and villages (Possehl, 2002).

The bead factory is one of the most interesting features of the Piggott's Period Ic occupation, and has been taken to indicate 


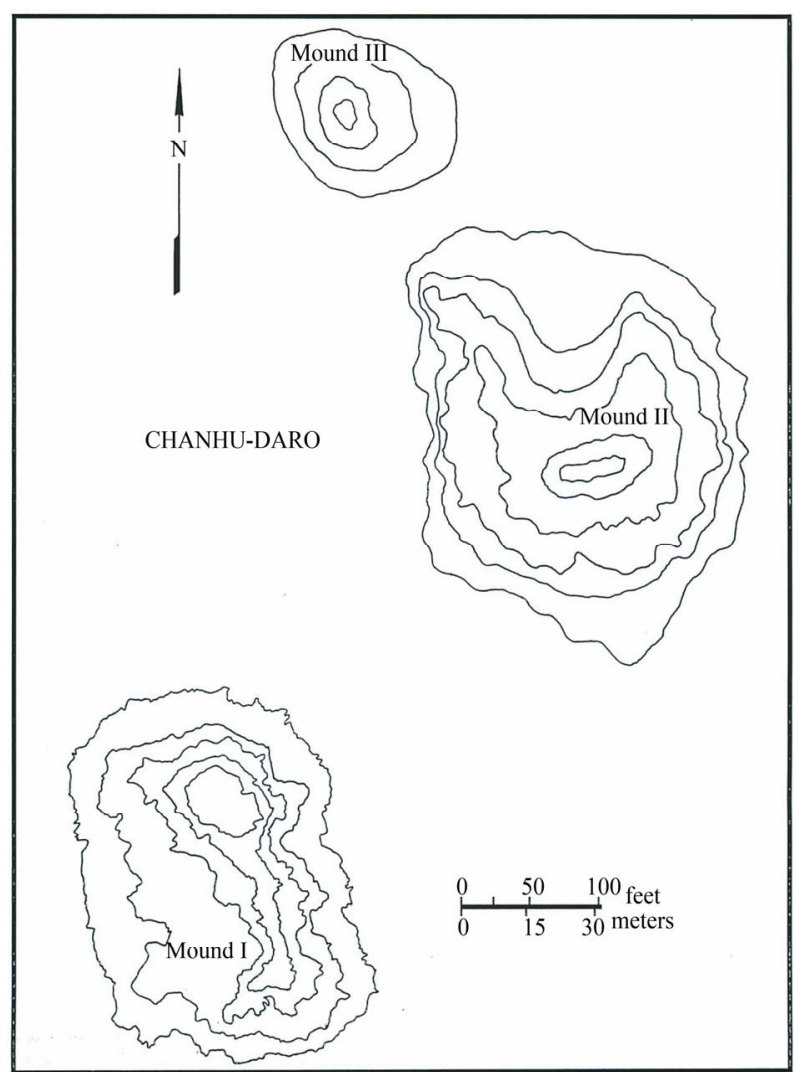

Figure 2.

Plan of Chanhu-daro. After Mackay 1943: Plate 1.

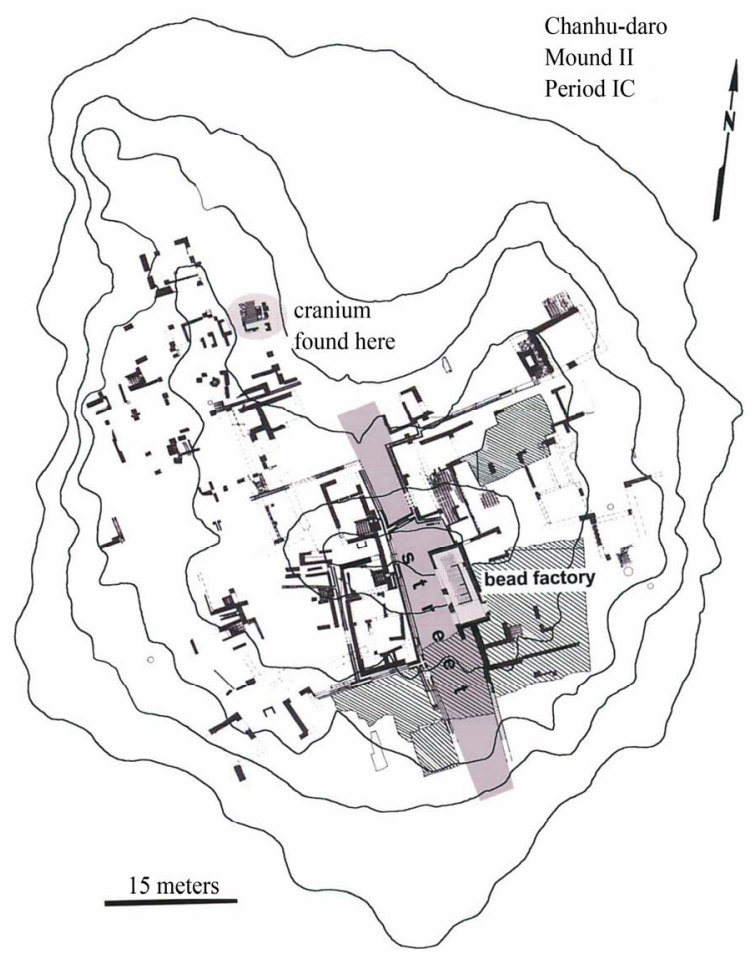

Figure 3.

Plan of Mound, with street and bead factory, After Mackay 1943: Figure 4.

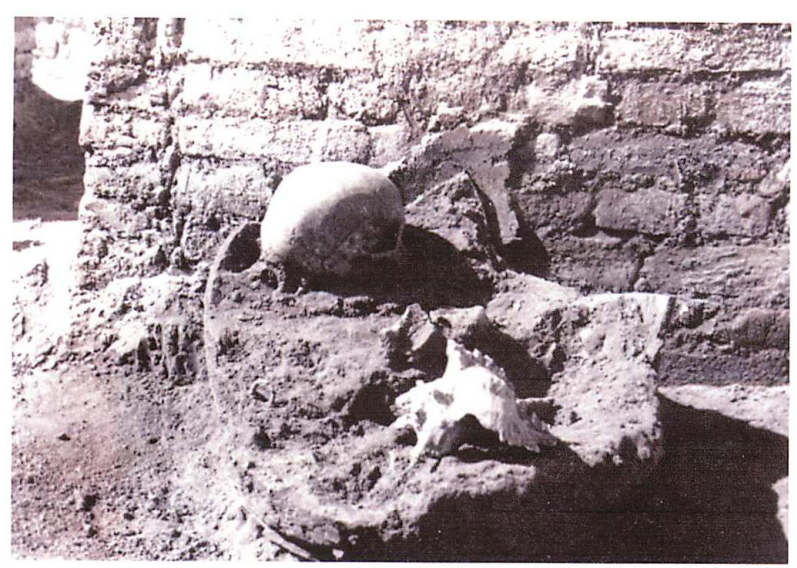

Figure 4.

The burial jar. After Mackay 1943: Plate XCIV, Figure 1.

that there was a significant amount of craft activity at the site (Mackay, 1943). The centerpiece of this installation was a furnace which would have been used in several ways, including the glazing of steatite, providing heat to bring out the red color of carnelian and to prepare stone for better chipping, also a part of the bead making process. Interest in the craft industry at Chanhu-daro has not been overlooked. G. M. Shar and M. Vidale (1985). Their findings and observations cannot be assigned to any particular period, but it is most likely to be the latter Mature Harappan. They confirmed the presence of massive amounts of craft activity here, especially noting the presence of kiln wasters, associated with the production of pottery. Finds associated with lapidary works further strengthen the sense that the site was a major bead and seal production center. The scale and diversity of this craft activity is important for our interprettation of Chanhu-daro and the cranium found there since it appears that its inhabitants were producing more of the same products than they were consuming. This leads to the inference that they were involved in trade, with the possibility that they were, either directly or indirectly, in contact with distant peoples and places.

About $40 \mathrm{~m}$ to the northwest of the bead factory and furnace Mackay discovered the pot within which the cranium we are discussing was found (Figure 4). He described the find spot as a well conditioned pavement of two courses of brick (locus 302; sq. 7/E). This seems to have been the floor of a bathroom in the house beyond to the west. This measured 7 feet 10 inches long by 5 feet wide, but the walls around it had been removed for the sake of their bricks and the room may actually have been larger. The storage jar on the eastern side served to drain this floor, and in it was found a human cranium a large shell, a copper or bronze ring, and a few other implements of copper or bronze, some of which were broken very rarely is something of value found in a drainage jar, save objects that have been washed in accidentally. This notable exception has proved of the greatest interest, as the report of this cranium, as described by Drs. W. M. Krogman and W. H. Sassamain (1943) will show. In their study of the Chanhu-daro specimen, they include in their report three line drawings of the frontal left lateral and superior aspects. Why this cranium was buried here without the rest of the skeleton, and whether it had any bones as yet undiscovered at the site remains unknown.

The cranium (a skull minus its mandible) was given the 
number $3324 \mathrm{k}$. It was found at a level of $2.80 \mathrm{~m}$ above the datum point at Locus 324 in Square 7/E at Mound II. Above and around the jar were the brickwork structures already noted, their weight and the pressure of the earth having cracked the jar to a considerable degree. This is the only human skeletal material that Mackay notes in his report of excavations at Chanhudaro. However, there are photographs in the Archives of the University of Pennsylvania Museum of at least three other interments. These were found relatively close to the surface of the site, and Mackay seems to have decided that they were not associated with the Bronze Age occupation. No grave goods are visible in the photographs, but further study might lead to interesting results.

\section{Taphonomy}

Under Mackay's supervision, the upper portions of the cranial vault and face were cleared of dirt and the cranial base and palate remained in the matrix. Once lifted from the jar the specimen was coated with paraffin was, a preservation method in common use at that time. After the excavation it was a sent to Professor Wilton Krogman, who, at the Laboratory of Anatomy at Western Reserve University (now Case Western Reserve University) in Cleveland, cleared the specimen of its soil matrix, noting the absence of a mandible and vertebrae. He concluded that these parts had been separated from the cranium prior to its deposition in the jar, and that "a sufficient period of time between death and interment (of the skull) had elapsed to permit the complete disassociation of the skull from a vertebral column and upper jaw from lower jaw" (Figure 3) (Krogman \& Sassaman, 1943).

What is unique at Chanhu-daro is not the practice of jar (urn, pot) containing portions of human skeletal remains, as this occurs at other pre-, post, and Mature Harappan sites. But it is the disposition of a single cranium in a jar that is unexpected. Nor is the Chanhu-daro specimen associated with a cemetery, as are a majority of the skeletons from Harappan sites. These cemeteries are usually positioned away from habitation areas. The diversity of methods for disposing and complete interments as well as fractional interments. There are 17 distinct archaeological contexts of Harappan customs for disposal of the deal (Possehl, 2002; Singh, 1970).

This may be an unusual circumstance of secondary burial since the body could have decomposed at some location away from the area of burial for the cranium. Whatever happend3ed to the rest of the body is not known, but it could be that the cranium was collected from this area and eventually (a day, a week, a month, a year?) deposited at the find site.

We have Mackay's testimony that the Chanhu-daro burial contained valuable, high-end objects of bronze or copper, along with a large sea shell. This was unusual. The cranium is also unusual in and of itself. As will be seen below, there is reason to believe it was that of a woman who could be considered an "exotic" foreigner in the contexts of the Indus Civilization. This gives us reason to believe that the artifacts, the shell and the cranium, should be associated together, possibly deposited in the jar at the same time as a kind of cache. It could even be that the cranium was disassociated from the rest of the woman's body immediately or shortly following her death. The soft tissues could have been macerated by placing the relatively fresh cranium in boiling water, or otherwise processed, and this vestige of this individual was kept by its "owner" along with the bronze/copper artifacts and sea shell (Figure 4).

\section{Anatomical Observations}

The cranium is well preserved except for some postmortem damage to the squamous portion of the left temporal bone. The bones of the inner ear are fragmentary, and missing are the right stapes and left stapes and incus. A number of anthropometric measurements and indices were taken by Krogman and his associate. Unfortunately, they did not measure or describe the maxillary teeth still embedded in their alveoli: left central and lateral incisors, second premolar and first molar; right first and second molars. The rest of the erupted permanent teeth were lost postmortem, as indicated by the sharp edges of their alveoli and nonexistence of any bone resorption in the upper gnathic region. The absence of erupted third molars, usually an indicator of the late juvenile/young adult age status of an individual, may in this specimen be a case of third molar agenesis. Radiographic examination did not show any trace of these teeth in the region posterior to the second molars. This is an anomaly, not a pathological condition. The left first molar shows a small carious lesion. Since the soil matrix did not contain the missing teeth, it is likely that they had been lost antimortum (Figures 5-10). These photographs attributed to Mackay (1943) do not include metric scales.

\section{Morphometric Analysis Figures}

\section{Methodology}

Anthropometric measurements taken by Krogman and Sassaman (1943) were influenced by the procedures described by Rudolph Martin (1864-1923) (1928) and Geoffrey Miles Morant (1899-1964) (1922-1923). However, the codes represented in Table 1 are no longer used in modern morphometric studies. The instruments included spreading and sliding calipers, steel metric tape, a Molleson craniostat, a dioptrographic drawing
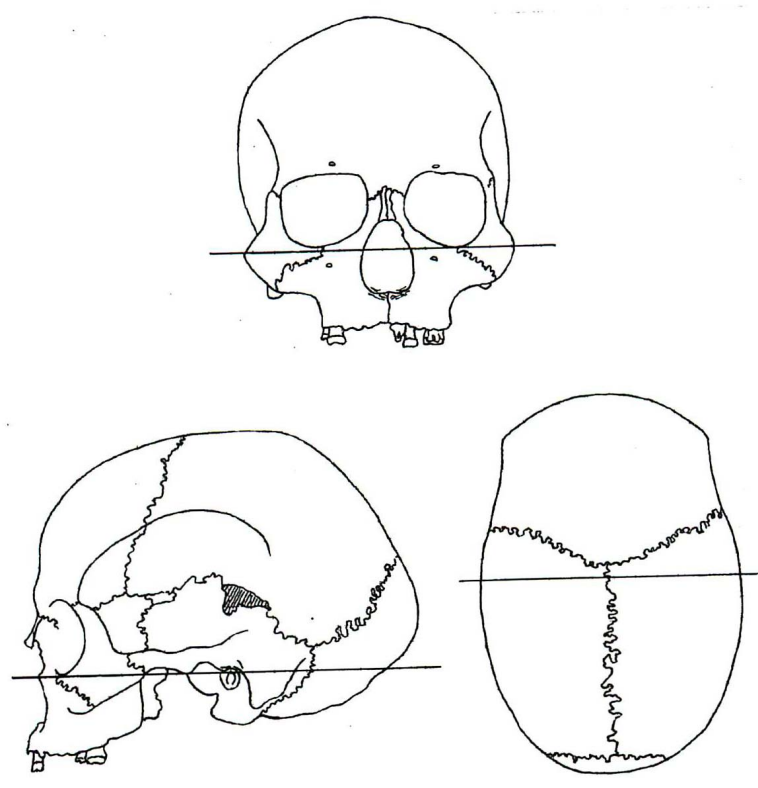

Figure 5.

Three diaoptographic drawings of the Chanhu-daro cranium by Krogman and Sassaman 1943. Plat XCVI. 


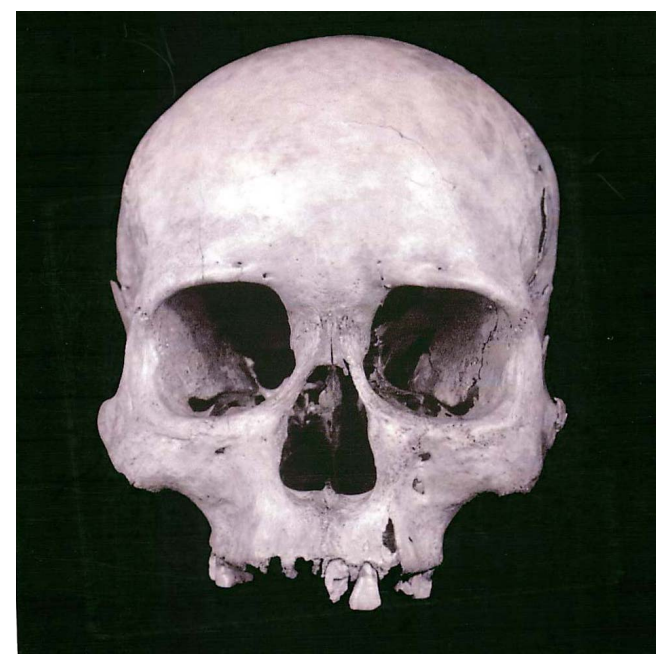

Figure 6.

The Chanhu-daro cranium, frontal aspect. After Mackay 1943: Plate XCV, Figure 6.

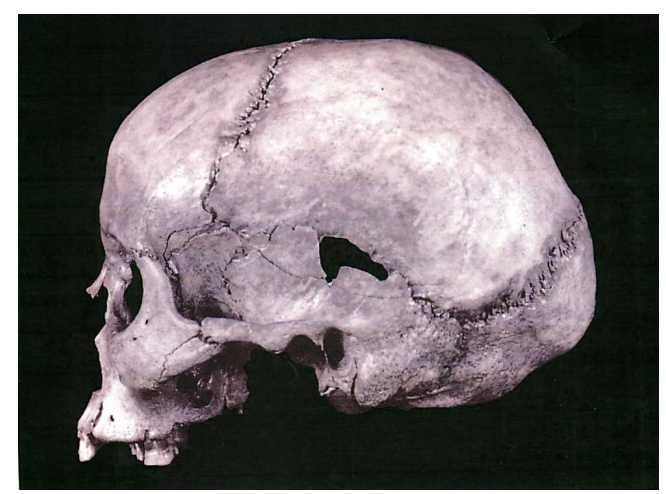

Figure 7.

The Chanhu-daro cranium, left lateral aspect. After Mackay 1943: Plate XCV, Figure 6.

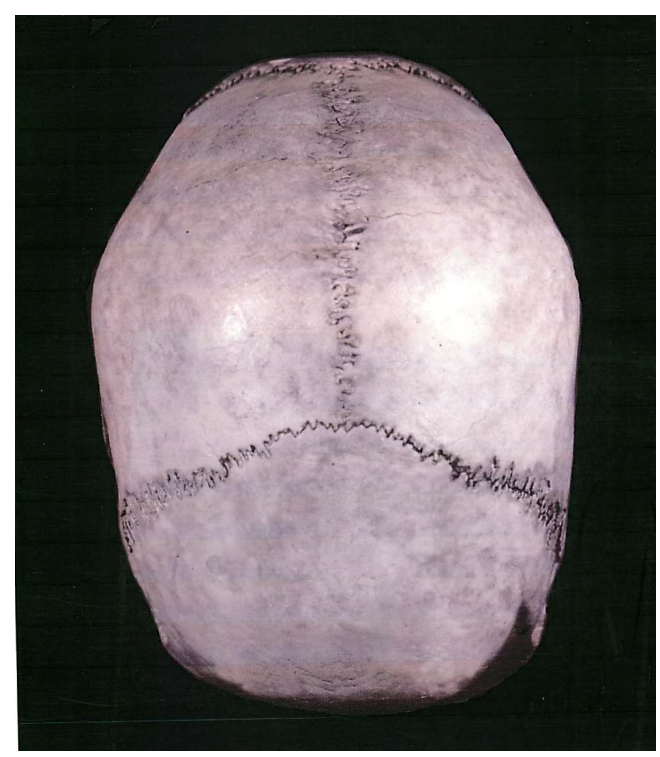

Figure 8.

The Chanhu-daro cranium, superor aspect. After Mackay 1943, Plate XCV, Figure 7.

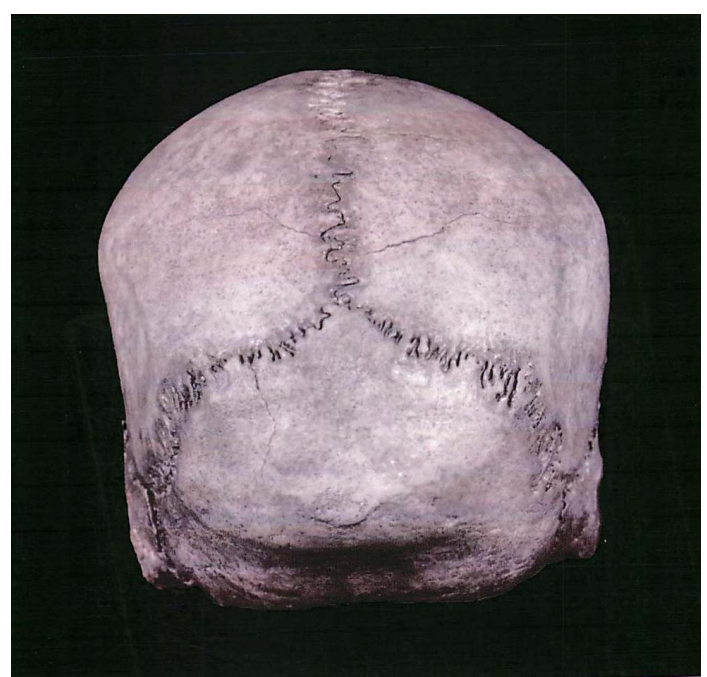

Figure 9.

The Chanhu-daro cranium, occipital aspect. After Mackay 1943, Plate XCV, Figure 8.

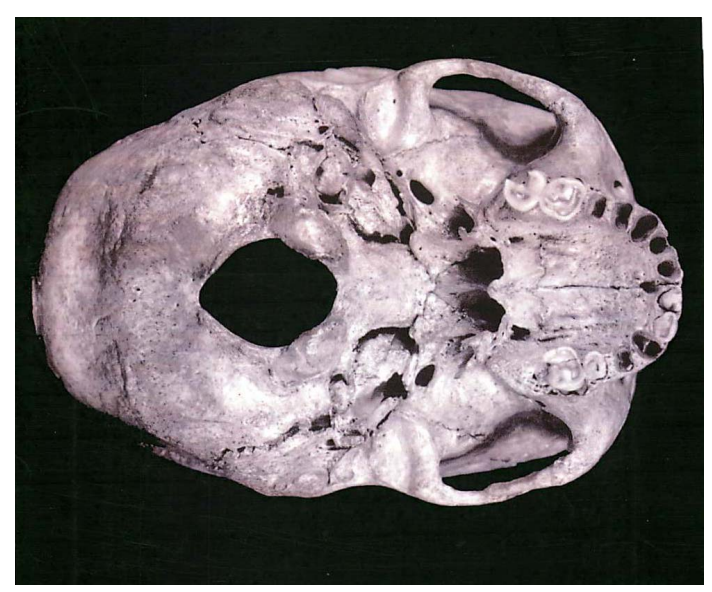

Figure 10.

The Chanhu-daro cranium, basalar aspect. After Mackay 1943, Plate XCV, Figure 9.

instrument and a Broadbent-Bolton roentgenographic cephalometer. Measurements were taken in mm units. For the cranial vault, 14 measurements and 5 indices were recorded; for the analysis. One of the present authors calculated from their dioptrographic drawings and angle of 78 degrees and the Nasospinale-Prosthion Frankfort Plan an angle of 80 degrees. These angle measurements follow the procedures defined as cranial code numbers 72 b and 73 respectively by Rainer Knussmann (1988). From the metrical data reported in Table 1 of the present study, it was possible to estimate the cranial capacity using the Lee-Pearson (1901) formulae for adult "White" females for Basion-Bregma Height $\left(1244.05 \mathrm{~cm}^{3}\right)$ and Auricular Height $\left(1181.27 \mathrm{~cm}^{3}\right)$. These volume game a mean cranial capacity of $1212.66 \mathrm{~cm}^{3}$ based upon an average of ten calculations of anthropometric data. In their summary of the Chanhu-daro cranium, Krogmann and his associate conclude that it had belonged to a young adult female, given the relatively small size of the cranial vault, small mastoid processes, low supraorbital ridges, smoothly rounded occiput, low nuchal crests and small inion. Age at time of death was estimated to be between 22 and 
Table 1.

Cranial measurements and indices of the Chanhu-daro skull.

\begin{tabular}{|c|c|}
\hline Maximum length (1) & 178.0 \\
\hline \multirow[t]{2}{*}{ Minimum breadth (b) } & 126.5 \\
\hline & 22 \\
\hline Minimum frontal breadth (b’) & 97.0 \\
\hline Basio-bregmatic height (h’) & 123.0 \\
\hline \multirow[t]{2}{*}{ Auricular-vertical height (oh) } & 108.0 \\
\hline & 22 \\
\hline Basi-nasal length (lb) & 94.0 \\
\hline \multirow[t]{2}{*}{ Basi-prosthion length (gl) } & 92.0 \\
\hline & 22 \\
\hline Transverse arc (q') & 279.0 \\
\hline Sagittal arc (s) & 353.0 \\
\hline Nasion-bregma arc $\left(\mathrm{s}_{1}\right)$ & 126.0 \\
\hline Bregma-lambda arc $\left(\mathrm{s}_{2}\right)$ & 116.0 \\
\hline Lambda-opisthion arc $\left(\mathrm{s}_{3}\right)$ & 111.0 \\
\hline Horizontal circumference (u) & 492.0 \\
\hline Bi-asterionic breadth & 98.0 \\
\hline Cranial index (b × 100/l) & 71.07 \\
\hline Height-length index $\left(h^{\prime} \times 100 / l\right)$ & 69.10 \\
\hline Height-breadth index (h’ × 100/b) & 97.23 \\
\hline $\begin{array}{l}\text { Transverse fronto-parietal index } \\
\left(b^{\prime} \times 100 / b\right)\end{array}$ & 76.68 \\
\hline Gnathic index (gl. × 100/lb) & 97.87 \\
\hline
\end{tabular}

25 years. The basi-occipital suture was closed and sutures of the cranial vault and face are patent. Muscular attachments are not prominent. Endocranial margins of venous sinus grooves and meningeal sulci are shallow and have rounded edges. With the assistance of the anatomist T. Wingate Todd (1884-1938) (1932) of (Case) Western Reserve University, Krogman and Sassaman learned that "The skull is that of an individual with a good health history". However, vascular pitting on the right and left parietal bones was interpreted as "evidence of a slight nutriational disturbance in childhood”, a disease marker we would attribute today to an anemic condition brought on by iron deficiency, malaria, or abnormal hemoglobins among other pathological possibilities.

The shape of the cranial vault is long and narrow (dolichocranic) and its elevation from the cranial base is low (chamaecranic), but it is somewhat broader in its cranial length/height ration (metriocranic). The ratio of the breadth of the frontal bone to the breadth across the two parietal bones brings the specimen within the indicial category of possessing a relatively broad forehead (eurymetroic). Indicial categories of the upper facial region indicate it is broad and low (euryenic), and the orbits have a low height/breadth ratio (chamaeconchic). The nasal aperture is broad (chamaerrhinic). In the mid-facial al- veolar tooth-bearing region of the maxilla there is considerable anterior projection, and the indicial values fall between the extremes of alveolar projection (prognathic) and a more moderate degree of alveolar projection (mesognathic), as determined by measurements of the Nasion-Prosthion/Frankfort Plan and Nasospinale-Frankfort Plan respectively. The latter degree of facial projection indicates the commencement of prognathy from the nasal root to the landmark Prosthion at the anterior-inferior margin of the alveolar region along the mid-line projection of the face. Given these measurements, taken by one of the present authors but not by the earlier investigators, it is curious that Krogman and Sassaman described the face as "broad, low, flat and only slightly projecting”, thereby assigning their facial and vault measurements to "contrasting-disharmonic features". This conclusion demonstrates that the Chanhu-daro lady was raising some unanticipated problems given their traditional racial classificatory scheme of how the denizens of the Indus Civilization cities and town should appear! (Table 2)

Table 2.

Facial measurements and indicies of the Chanhu-daro skull.

\begin{tabular}{|c|c|}
\hline \multicolumn{2}{|l|}{ Total facial height (na-gn gn) } \\
\hline Upper facial height, na-pros (g’h) & $61.0 \mathrm{~mm}$ \\
\hline Mid-face breadth (gb) & 101.0 \\
\hline Bizygomatic breadth (j) & 124.0 \\
\hline Nasal height (nhl) & 48.5 \\
\hline Nasal breadth (nb) & 25.0 \\
\hline \multicolumn{2}{|l|}{ Interorbital breadth (dc) } \\
\hline Orbital breadth $\left(0_{1} \mathrm{l}\right)$ & 43.0 \\
\hline Orbital height $\left(0_{s} \mathrm{l}\right)$ & 32.5 \\
\hline Palatal length (gl') & 44.5 \\
\hline Palatal breadth (g2) & 39.0 \\
\hline Foramen magnum length (fml) & 37.0 \\
\hline Foramen magnum breadth (Fmb) & 30.0 \\
\hline \multicolumn{2}{|l|}{ Total facial index $(\mathrm{gh} \times 100 / \mathrm{j})$} \\
\hline Upper facial index $\left(g^{\prime} h \times 100 / j\right)$ & 49.03 \\
\hline \multicolumn{2}{|l|}{ Total mid-facial index $(\mathrm{gh} \times 100 / \mathrm{gb})$} \\
\hline Upper mid-facial index (g’h × 100/gb) & 60.39 \\
\hline Nasal index (nb × 100/gb) & 51.55 \\
\hline Orbital index $\left(0_{2} \mathrm{l} \times \mathrm{l} \times 100 / \mathrm{o}_{\mathrm{l}^{\prime} \mathrm{l}}\right)$ & 75.58 \\
\hline Palatal index $\left(\mathrm{g}^{2 \times 100^{\circ} \mathrm{gl},}\right)$ & 89.88 \\
\hline Foraminal index $(\mathrm{fmb} \times 100 \mathrm{fml})$ & 81.18 \\
\hline Transverse cranio-facial index $(\mathrm{j} \times$ × 100/b) & 98.02 \\
\hline
\end{tabular}




\section{Morphological Data}

In additional to the cranial size and shape variables noted above, morphological analysis reveals a rounded glabella, a plain frontonasal junction, a rounded and rather bulbous frontal contour with a median frontal eminence, a slight sagittal plateau with a trace of postbregmatic depression, a rounded occipital contour forming an occiput en chignon (prominent bulging of the occipital when the cranium is viewed from its posterior aspect (norma occipitalis). From this point of observation, the cranium assumes a pentagonal form. This shape is due to prominent left and right parietal eminences. The vertical aspect reveals that the cranium has an elongated ovoid form. There is an os epiptericum on left and right sides of the vault. The pterionic regions are $\mathrm{H}$-shaped. There is moderate occipital bunning.

Facial morphology is characterized by a broad nasal aperture with "troughed" or "guttered" sills at the inferior margins of the cavity. The interorbital width, while not recorded in the Krogman and Sassaman table of measurements, is described in their text as "rather narrow, with the upper half of the nasal bones excessively narrow". They have described the orbits as "slightly angular", but the photograph of the cranium's facial aspect (norma facialis) indicates it has more rectangular form, particularly for the left orbit. There is neither postorbital constriction nor prominent temporal fullness. The inferior margins of the nasal cavity are dull (orygmocraspedotic) and do not exhibit sharp edges. A striking feature of the face, when viewed from the left lateral aspect (norma lateralis sinistrum) is its prognatheous alveolar region. This feature is confirmed by the indicial values and angles discussed above. But the cranial vault and face are not elevated. The form of the palatal arcade is parabolic and it is very wide across the alveolar area containing the incisors and canines. The palatal suture is relatively even with a slight posteriorly directed rippling at the mid-line. There is no anterior "bulging" of the suture at this region. Palatal depth was not recorded (Figures 6-10).

Given these anthropometric and morphological data should we ascribe the Chanhu-daro female as falling within the range of phenotypic diversity of the widely scattered populations of the Indus Civilization, as determined by a comparative study of human skeletal remains recovered and scientifically examined from other sites within its cultural domain, or can her ancestry be traced to populations living well outside its borders, i.e. was she of "foreign" birth?

Absence of dental morphometric for the Chanhu-daro specimen precludes the use of dental train analysis. The maxillary teeth include LI1, LI2, LM2, LPM2.RM1, RM2 (I = incisor, $\mathrm{PM}=$ premolar, $\mathrm{M}=$ molar). Earlier studies of the dental features of Indus Civilization crania support the hypothesis that ancient populations settled along the Indus and Ravi Rivers were indigenous and not derived from some invading outside populations (Hawkey, 1998, 2004). That is the Harappan populations showed revealed close genetic similarities to earlier hunting-gathering populations or the Veddas of Sri Lanka this value is 0.086 . Dental phenotypic variables also indicate that gene flow between the Indus region and Egypt (MMD $=0.124)$ and values for the ancient Kingdom of Nubia (MMD $=0.088$ ) suggests that these values were applicable at the times of the Mature and post Harappan phases (Hawkey, 1998, 2004).

The biological anthropologist S. O. Y. Keita (1988) lists 13 craniofacial components with significant heritability that are useful in population affinity assessment. Sufficient data for nine of these measurements (Maximum Cranial Length, Maximum Cranial Breadth, Basio-Bregma Height, Bizygomatic Breadth, Upper Facial Height, Minimum Frontal Breadth, Minimum Frontal Breadth, Nasal Height, Nasal Breadth) were recorded for females of ten other Harappan females.

The Chanhu-daro female and other females from the burials at the Mature Phase of Harappa cemetery R37 and the Late Phase jar burials are from the adjacent Harappa cemetery $\mathrm{H}$ are compared for both size and shape components. Two of the Indus Civilization burial areas at Harappa have skeletons that reveal closest similarities with Chanhu-daro in size, but only a moderate similarity in shape (Harappa R37 size $=0.063$, shape = 0.426; Harappa cemetery $\mathrm{H}$ size $=0.043$, shape $=0.529$ ).

Absence of dental morphometric data for the Chanhu-daro specimen precludes use of dental trait analysis. The maxillary teeth present are LPM2, LM1, LPM2.LM1, LI1, LM2, M1 and LM2 ( $\mathrm{L}$ = left side of the palate, $\mathrm{I}$ = incisor; $\mathrm{PM}=$ premolar, $\mathrm{M}$ = molar). Earlier studies of the dental features of Indus Civilization specimens support the hypothesis that populations along the Indus and Ravi Rivers were indigenous and not derived from some invading foreign population (Hawkey 1998, 2004). That is, the Indus population showed close genetic similarities to earlier hunting-gathering populations of the Indian subcontinent (Mean Measure of Divergence $=0.022$; for historic Veddas of Sri Lanka this value is 0.086). Dental phenotypic similarities also suggest that there had been gene flow between the Indus region and Egypt $(\mathrm{MMD}=0.124)$ and New Kingdom Nubia (MMD $=0.088$ ) was probable at the time of the Mature and Late Harappan Phases (Hawkey, 1998, 2004).

\section{Archaeological Observations}

\section{Economic Trade Contacts}

The third millennium BC was a time of unique economic and political configurations in a part of the world that can be called "Middle Asia", the region between the Indus and the Mediterranean, bounded on the north by Afghanistan and Central Asia and on the south by the Arabian Gulf. By the middle of the third measureable upsurge in economic activity and "intercomnectedness" in Middle Asia. This economic development linked the Indus Civilization with Mesopotamia by sea and across the Iranian plateau. It also strengthened the ties between the Indus and Central Asia. Taken as a whole, we have what archaeologists call the "Middle Asian Interaction Sphere" (MAIS) (Possehl, 2002).

Archaeologists first learned of this interaction sphere through Indus stamp seals that were found in Mesopotamia. Cuneiform texts also mentioned maritime trade between Mesopotamia and the Indus Civilization, a place called "Meluhha", through locations called "Dilmun” (modern Bahrain) and "Magan” (Oman) were also cited (Oppenheim, 1954; Possehl, 1996). The presence of Indus pottery in the Gulf and Oman, at some sites in considerable quantity (Mery, 2000; Cleuziou \& Tosi, 2000; Carter, 2001), as well as Indus seals, weights, beads, combs and the like document the presence of Indus commerence and sailors in these areas (Possehl, 1997).

The maritime trade linking ancient India to Mesopotamia is documented by historical records, and by archaeology. There is also evidence that this intercourse extended down the eastern coast of Arabia to the mouth of the Red Sea (Wright, 2011). 
The clearest of these indicators is the presence of African millets in the subcontinent in prehistoric times, which has been discussed for a number of years (Mehra, 1963; Vishnu-Mittre, 1974) (Figure 11). The principal large seed summer grasses in South Asia are sorghum or jowar (Sorghum bicolor), pearl millet or bajra (Pennisetum typhoides) and finger millet (Elleusine coracana). All are endemic across a broad band of sub-Saharan Africa, that has its eastern terminus in Ethiopia and the mouth of the Red Sea (Figure 11).

Botanists, interested in the history of domestication, have discussed this in a number of places (Harlan \& Stemler, 1976; Harlen, deWet, \& Stemler, 1976; Harlen, 1992) and it appears to be an established fact. Harlan (1992) has produced two maps that are important to understanding the domestication and spread of sorghum and pearl millet. On the first map, circles indicate location of wild pearl millet, Pennisetum violaceum; dark shading indicates the northern pearl millet belt; light shading indicates areas in which pearl millet is grown, but in which sorghum is the dominent crop. Sorghum is present at the site of Hili 8 in Oman. It comes from Phase IIe, which can be dated to 2330-2250 BC (Cleuziou \& Costantini, 1980) who write that sorghum was probably cultivated around Hili. Costantini (1990) has also documented the presence of these millets in Yemen at sites dated to the second half of the third millennium BC. These same three millets are all documented in India and Pakistan at sites dated from 2400 to 1800 BC (Possehl, 1997). These include Hulas, Rohira, Rojdi B and C, Rangpur III, Babar Kot, Surkotada and Daimmabad (Possehl, 1997, 2002).

Sailors, and probably sailing families, seeking a livelihood, pioneered the route from the Subcontinent to the Gulf region and on to Africa (Gogte, 2000). In 1952 Carl O. Sauer (1952, 1969) suggested that this coastal route "may be a great lost corridor of mankind”. While these sailors were in African waters they would have come into contact with the foods of the local population. They may have brought food of their own, but

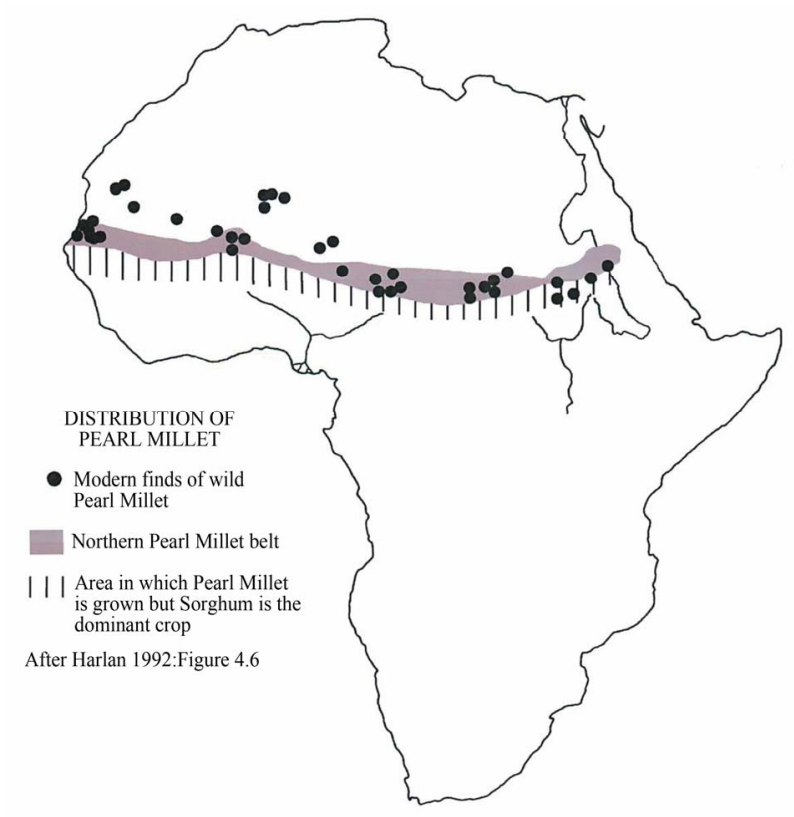

Figure 11.

Distribution of pearl millet and sorgum in Africa. After Harlan 1992. boats were small and drawing on local grain and meat would have made good sense. It is in this context that the African millets were taken on board boats and brought to places like Oman, Pakistan and India. When the millets were domesticated is a question that remains to be settled, but the probability exists that one or more species were not domesticated but wild, or in one of those states of limbo in food production, between wild and fully domesticated (Sauer, 1969).

These millets are drought resistant and amenable to dry cropping. They are hearty and require little tending as they mature. They have large seeds on commodious heads covered with nourishing grain and can be productive and efficiently harvested. They also grow in hot weather, and were adapted to the summer monsoon growing of the Subcontinent. These are the principal reasons for their adoption by the ancient Indian farmer.

The millets tell us in a remarkable way that sailors reached the mouth of the Red Sea. These may have been Indus people themselves, although less direct contact is also possible, and complementary to this scenario. In any event, the millets were taken back to the Subcontinent and integrated into the lives of the Indus peoples. Given this historical context, it is reasonable to believe that humans migrated from East Africa to "Magan" or "Meluhha". Their social status ("slave" or "free" or somewhere along the multidimensional social continuum between these categories) is not known, but the Chanhu-daro cranium would seem to offer strong support of this suggestion.

\section{The Bronze “Dancing Girl” (Figures 12 and 13)}

We would be remiss not to mention the fact that the E. C. L. During Caspers (1987) has suggested that the so-called "Bronze Dancing Girl” from HR area of Mohenjo-daro is a representation of a Nubian. A second "Bronze Dancing Girl" was recovered from the DK area of Mohenjo-daro but it is too corroded to be a serious part of this discussion.

Depictions of persons with obvious "racial" physical and dress styles appear in ancient Mesopotamian cultures, namely carved figurines and paintings, but the only sculptures from the Harappans is the figure of the "dancing girl" at Mohenjodaro (Breasted, 1944).

The statuette of the young woman was found by Sahni during the 1926-1927 field session within a house structure of Block 7 in the area Hr5721. The figure is $10.8 \mathrm{~cm}$ in height. Her trunk is relatively short and the extremities long in her linear build from the HRr 5721. This is a splendid piece of copper-bronze casting She was cast by the cire perdue technique and may well be a portrait of an individual living at that time. This piece of Harappan art has been discussed elsewhere (Possehl, 2002). She is $10.8 \mathrm{~cm}$ high and was cast using the lost wax process. The statuette was found in a Late Level house at Block 7 by D. R. Sahni (1879-1939) (1926, 1927) during the 1926 and 1927 field season. The house is a small structure deep within the southwestern quarter of the city.

The figure is a very thin young woman, standing upright, with her head tilted slightly back, her left leg bent at the knee. There is little sense of flesh on the body, and upper and lower limbs are gracile and do not exhibit prominent muscular anatomy. Her right arm is bent, with her hand placed provocatively on the back of the hip, the thumb beside a clenched fist. The left arm rests slightly bent on her left thigh. The thumb and forefinger of this hand form a circle, and it is apparent that she 


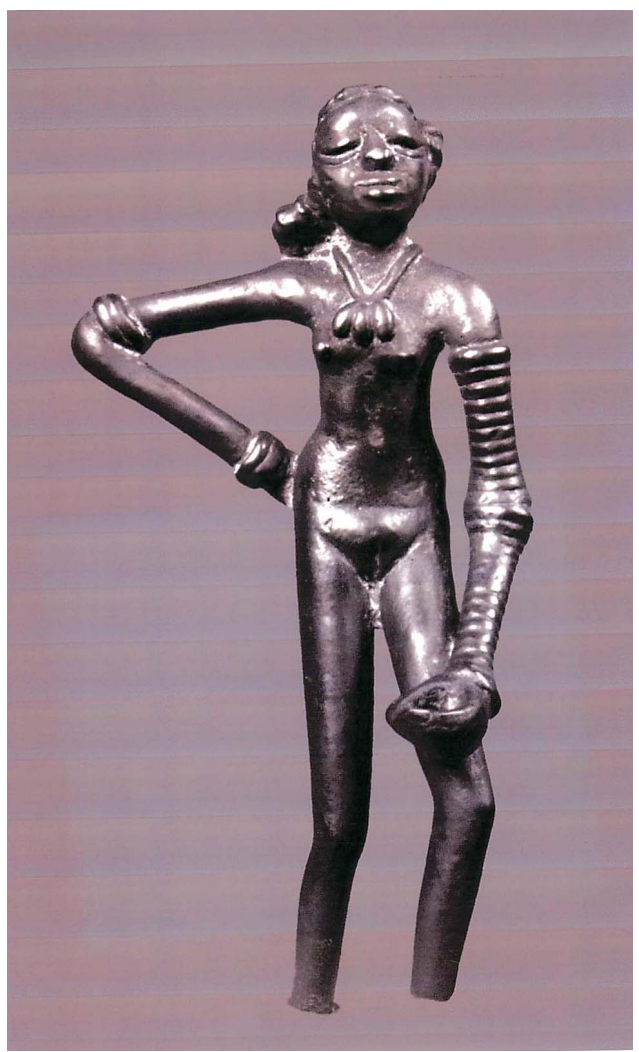

Figure 12.

Figure of the "dancing girl" from Mohenjo-daro. After Harlen 1992. Anterior aspect.

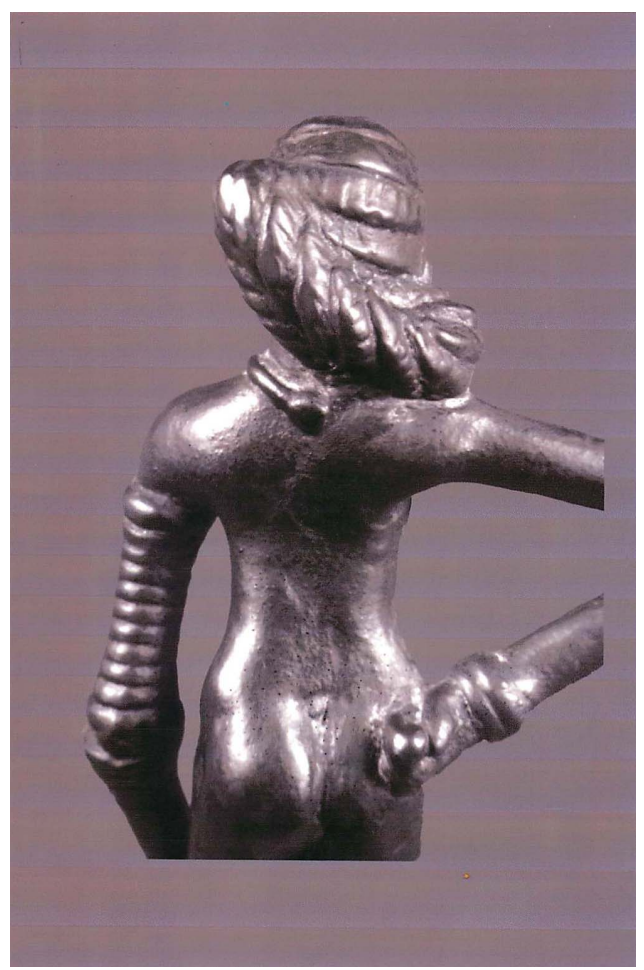

Figure 13.

Figure of the "dancing girl" from Mohenjo-daro. After Harlen Posterior aspect. once held a small object, possibly a baton of some kind. She is naked except for some ornaments. Around her neck is a small necklace with three large pendant beads. On the left arm she wears 24 or 25 bangles. The right arm has four bangles, two at the wrist and two above the elbow. Her hair is coifed into a loose bun, held in place along the back of the head, in much the same way as some Indian women wear their hair today. The artist has rendered this feature in detail, and it is worth noting that the hair could be called wavy. It is not a spiral hair form such as occurs in some modern populations from Nubia. However, we cannot outrule the possibility that this is a headpiece, such as a wig, or that the naturally tight curley hair of many Africans had been artificially straightened. Whether this small statuette actually portrays a dancer is open to question. Only the pose seems to convey this.

Some scholars have proposed that the broad nose, large membranous lips, the anterior projection of the tooth-bearing portion of the face, and the linearity and proportions of the upper and lower extremities suggest a Nubian (Caspers, 1987); a Proto-Australoid (Piggott, 1950). Piggott wrote in a reference to her that: "when we are describing the Harappa culture, I think I recognize a Kulli girl in a "foreign city". He thought that her hair style was like that found on terra cotta figurines of the Kulli peoples, a view that the present authors do not share. Sir John Marshall (1931) caught something special in the figure: It give him a "vivid impression of a young aboriginal nautch girl, her hand on hip in a half-impudent pose with legs slightly forward, as she beats time to the music with her legs and fee $\cdots$ the modeling of the back, hips and buttocks is quite effective".

The statuette was a favorite of Sir Mortimer Wheeler (Hawkes, 1982). He described her thusly: "There is her little Baluchi-style face with pouting lips and insolent look in the eye. She's about fifteen years old I should think, not more, but she stands there with bangles all the way up her arm and nothing else on. A girl perfectly for the moment, perfectly confident of herself and the world. There is nothing like her". The present authors regard the Bronze Dancing Girl from the HR are of Mohenjo-daro as "a splendid piece of Indus art, but it cannot be demonstrated that it is a representation of an African. However, her body proportions of a relatively short trunk and long upper and lower extremities fit the essence of Bergmann's Rule (Bergmann, 1847; Ruff, 2002) that (African) equatorial populations are best adapted to heat loss under conditions of high solar radiation and humidity by this type of body form. Settled north of the Tropic of Cancer at some 30 degrees north of the Equator in the southern Temperate Zone, the ancient inhabitants of the Indus and Ravi Rivers do not exhibit these features, as determined by analysis of their skeletal remains.

\section{Possible "Ancestry" of the Chanhu-Dara Female}

Morphometric of the Chanhu-daro cranium allow us to compare it to skeletal specimens recovered from other sites of the Indus realm. Previous research indicates that even within the Indus Valley of the third millennium BC there was considerable phenotypic diversity (Hemphill et al. 1991; Kennedy, 2000). The claims that the Harappans constituted a homogeneous "race" or even a new Bronze Age "sub-species", as advocated by P. C. Dutta (1983), has not been vindicated by recent morpho-metric data.

It is not surprising to encounter in both ancient and modern panmictic urban populations a wide range of biological diver- 
sity. But individual variation due to adaptive responses to genetic, cultural and environmental stresses were not viewed in this way by earlier anthropologists. Their conversions of "racial classifications" into schemes of "racial palaeontology" were based upon a concept that ancestral origins of an individual or population required their categorization into sub-specific natural entities. The traditional racial concept was based upon limited and arbitrarily selected frequencies of physical characters indicative of supposed natural divisions within Homo sapiens and classification of populations fitting into a hierarchial evolutionary progression from savagery to civilization. Erosion of this false notion, beginning about fifty years ago among systematic biologists and biological anthropologists, resulted from the recognition that classifications of sub-species of any organism, fossil or living, were invalid when conceived as natural biological species. Today the formerly designat "races" are understood to be Homo sapiens and distinctive from other hominin taxa because of reproductive isolation, reproductive isolation and by salient morphological differences. Geographical loci and trinomial appendages to species names for purposes of identification have replaced racial typology and taxonomy. Of course popular racial classifications prevail in our societies at the present time, but there are no valid scientific data to support "racial categories" arranged in a ladder of superior and inferior peoples, i.e. "Whites" or "Caucasians", "Blacks or Negroids”, “Mongoloids”, etc. (Gill \& Rhine, 1990; Kennedy, 1976, 1995).

Thus it is not unexpected that the first describers of the Chanhu-daro cranium sought to fit it into one of the racial classifications current during the first half of the last century. What is relevant to Krogman's and Sassaman's study is not that they placed Chanhu-daro with a "Proto-Mediterranean type" and compared it to other specimens assigned to this racial category, namely the skeletons from Mohenjo-daro and a Sialkot (a single skull collected in 1912 in the western Punjab) as well as specimens from Iran and the Near East. Rather it is significant that these American anthropologists recognized that the Chanhu-daro cranium was not a "perfect fit" within the sorting criteria of cranial traits used to define the macropopulations of the Indus Valley. They wrote that the specimen "is Negroid in its low flattened vault, in its broad nose with its "traughing" or slight sulcus praenasalis, in its diminished sub-nasal height and low orbits, and possibly its (cranial) length and occipital fullness” (Krogman \& Sassaman, 1943).

A notion held by many anthropologists of this period was that some physical "traits" encountered in modern African populations appeared in the phenotypic patterns of ancient and modern peoples of South Asia has a long and complex history. Precepts were modeled upon European taxonomy of plants and animals with its beginnings in the mid-eighteenth century. Carolus Linnaeus' (1701-1778) (1758) classification of the genus Homo was adopted and modified by anthropologists of the nineteenth century (Kennedy, 2000). The carry-over of racial classifications into British India was in place by 1901 with Herbert Risley's (1851-1911) (1901) publication of The Census of India 1901 (Risley \& Gait, 1903), and these were extended to include both skeletal and living populations by the American-trained biological anthropologist B. S. Guha (18941961) (1935) in the Census of India 1931.

As other racial classifications for the populations of the Indian subcontinent emerged, a persisting them was that a "Negroid" or "Negritoid" (pygmy) racial element was present, and was especially evident in southern India. Populations assigned to this type were considered to be "primitive" or of a "lower stratus”, both biologically and culturally. The small body size, spiral hair form, dark skin pigmentation and broad noses of certain tribal groups in Kerala led Guha $(1928,1929)$ to regard them as members of a "Negroid strain". It is possible that their physical features are not phenotypic parallels with some sub-Saharan or Nubian African peoples; they may be the result of genetic contributions of Africans escaping from slave ships plying the southeastern coast of India and mating with the tribal hunter-gatherers of the mainland. There are other cases of writers perceiving African or pygmy physical characters in prehistoric populations recovered from Indian Iron Age sites (Lapique, 1905; Thurston, 1909).

At this point in this discussion, the reader will have perceived that the Chanhu-daro female has many cranial features that do not fall within the range of variables encountered in the macropopulation of the Indus Valley, as this is understood today by anthropologists who have examined directly the skeletal series from cemetery collections at different Indus burial localities. These specimens tend to have long and narrow cranial vaults (dolichocranic) which are moderately elevated when measured from the base of the craniums to the highest point on the vault (mesocranic, and more frequently in males). But in both sexes there are specimens with low cranial vault heights (chamaecranic, and more frequently in females). As would be expected in a heterogenous population, some individuals of both sexes had very high cranial vaults (acrocranic). Since there are various technical methods for measuring the cranial vault height, it is not surprising that the indicial categories show some minor differences, but these anthropometric data can be summarized by noting that this feature ranging from low to high vaults is found in adults of both sexes.

The forms of the upper facial region vary from an extremely broad face, when straight-line measurements are taken across the cheek bones (mesene and eurene, especially in females) to narrow faces (leptene) measured in this same way. Measurements of the total face with its mandible attached (which is not applicable to the Chanhu-daro specimen which is lacking its lower jaw), reveal both broad (euryprosopic) to narrow (leptoprosopic) facial structures among the ancient people of the Indus valley. Broad noses (chamaerrhinic) and narrow noses (leptorrhinic) appear across the samples, females having somewhat narrower noses than males. Orbital forms vary from high (hypsiconchic) elevations to moderate elevations (mesochonicic). Measurements of the length and breadth of the nasal aperture yield indices within the medium (mesorrhinic) to narrow (leptorrhinic) categories for both sexes. But palatal shape and size differ significantly between the sexes, females more often possessing wider palates (brachystaphylinic) than males. Anterior projection of the upper and total facial regions is rare (prognathic) since straight profiles are in highest frequency (orthognathic).

Morphological features also distinguish the cranial specimens from several Harappan sites from the one at Chanhu-daro. Harappan skulls are generally robust with vertical frontal orientation, larger nuchal muscular attachments at the back of the head and temporal lines that are prominent and sweep posteriorly from the sides of the frontal bone to the parietal bones. Nasal sills are sharp (origmocraspedotic). Skulls are generally large for both males and femailes. These craniofacial properties are not in high frequencies among ancient and modern popula- 
tions of African ancestry (Gill \& Rhine, 1990; Byers, 2002), but, as noted above, certain African features appear in the cranium from Chanhu-daro. Her manner of death is unknown. At the time of this writing the Chanhu-daro cranium is lost, and efforts to locate it at the University of Chicago, Case Western Reserve University and the University of Pennsylvania have not been successful.

\section{Conclusion}

The human cranium from the Mature Harappan site of Chanhu-daro presents archaeologists with a unique funerary practice by the Indus peoples. While jar burials have been encountered in Early and Mature Harappan sites and continued into the Post-urban Jhukar culture, the Chanhu-daro cranium indicates it was a secondary burial. The cranium is not associated with postcranial bones of the original body. These had been disposed of elsewhere, possibly at a significant time prior to the insertion of the cranium into the jar.

Anthropometric and morphological analyses indicate that the cranium belonged to a young female in relatively good health as based upon absence of skeletal and dental markers of a pathological nature. The manner of her death is unknown. The hypothesis that the Chanhu-daro female was of African ancestry is supported by the results of comparative data from ten cranial-bearing from ancient and modern South Asia.

The notion that individuals of African descent were present in centers of the Indus Civilization is congruent with an emerging story of maritime activity in the Arabian Sea and the Arabian Gulf. It appears that Indus sailors, or others, reached the Horn of Africa where they acquired millets, adapted to a hot, wet summer growing season and brought millets to the Subcontinent. It may well be that the Chanhu-daro cranium informs us that Africans joined the Indus peoples on their sail back home and were resident in the Indus Valley during the second half of the third millennium BC.

\section{Acknowledgements}

Dr. Diane E. Hawkey is thanked for her participation in this historical study. The senior author was provided financial support from the National Science Foundation, the American Institute of Indian Studies, the American Institute of Pakistaln Studies and the Smithsonian Institution. Dr. Possehl's was funded by the Anthropology Museum of the University of Pennsylvania in Philadelphia, the American Institute of Indian Studies and other funding agencies.

\section{REFERENCES}

Bergmann, C. (1847). Uber die verhaltnisse der warmeokonomieder tiere zu ihrer grosse. Gottinger Studien, 3, 595.

Breasted, J. H. (1944). Ancient times: An introduction to the study or ancient history and the career of early man. Boston: Ginn and Company.

Byers, S. N. (2002). Introduction to forensic anthropology: A textbook. Boston: Allyn and Bacon.

Carter, R. A. (2001). Saar and its external relations: New evidence for interaction between Bahrain and Gujarat in the early 2nd millennium. Arabian Archaeology and Epography, 12, 183-201. doi:10.1034/j.1600-0471.2001.d01-5.x

Caspers, E. C. L. (1989). Was the dancing girl from Mohenjo-daro a Nubian? Rome: Note Discussionni.

Cleuziou, S., \& Costantini, L. (1980). Premiers elements sur l'agricul- ture protohistorique de l'Arabie orientale. Paleorient, 6, 245-251. doi:10.3406/paleo.1980.4278

Cleuziou, S., \& Tosi, M. (2000). Ra's al-Jinz and the prehistoric coastal cultures of the Ja'alan. Journal of Oman Studies, 11, 19-73.

Costantini, L. (1990). Ecology and farming of the protohistoric communities in the central Yemeni highlands. In A. deMaigre (Ed.), The Bronze Age culture of hawlan at-tiyal and al-hada (Republic of Yemen) (pp. 187-204). Rome: Instituto Italiano per il Medio de Estremo Oriente, Centro Studie Scavi Archeologici.

Crawford, H. E. W. (1998). Dilmun and its gulf neighbors. Cambridge: Cambridge University Press.

Dutta, P. C. (1983). The Bronze Age harappans. Calcutta: Anthropological Survey of India.

Gill, G. W., \& Rhine, S. (1990). Skeletal attribution of race: Methods for forensic anthropology. Anthropological Papers of the Maxwell Museum of Anthropology 4.

Gogte, V. D. (2000). Indo-Arabian maritime contacts during the Bronze Age: Scientific study of pottery from Ras al-Junayz (Oman). Admatu, 2, 7-14.

Guha, B. S. (1928). Negrito strain in India. Nature, 121, 793. doi: $10.1038 / 121793 a 0$

Guha, B. S. (1929). Negrito strain in India. Nature, 123, 342-343. doi:10.1038/123942b0

Guha, B. S. (1935). The racial affinities of the peoples of India. Census of India 1931. Simla: Government of India Press.

Harlen, J. R., de Wet, J. M. J., \& Stemler, A. (1976). Plant domestication and indigenous African agriculture. In J. R. Harlan (Ed.), Origin of African Plant Domestication (pp. 3-19). The Hague: Mouton. doi:10.1515/9783110806373.3

Harlen, J. R. (1992). Indigenous African agriculture. In C. Cowan, C. Wesley, \& P. J. Watson (Eds.). The Origins of Agriculture: An international perspective (pp. 59-70). Washington DC: Smithsonian Institution Press.

Hawkes, J. (1982). Adventurer in archaeology: The biography of sir mortimer wheeler. New York: St. Martin's Press.

Hawkey, D. E. (1998). Out of Asia: Dental evidence for affinity and microevolution of early and recent populations of India and Sri Lanka. Ph.D. Dissertation, Tempe, AZ: Arizona State University.

Hawkey, D. E. (2004). The peopling of South Asia: Evidence of affinities and microevolution of prehistoric populations of India and Sri Lanka. Spolia Zeylanica 39. Sri. Lanka: Colombia National Museums of Colombo.

Hemphill, B. C, Lukacs, J. R., \& Kennedy, K. A. R. (1991). Biological adaptations and affinities of Bronze Age Harappans. In R. H. Meadow (Ed.), Harappan excavations 1986-1990: A multidisciplinary approach to third millennium urbanization (pp. 137-192). Madison, WI: Prehistory Press.

Keita, S. O. Y. (1988). An analysis of crania from tell-duweir using multiple discrimiant functions. American Journal of Physical Anthropology, 75, 375-389. doi:10.1002/ajpa.1330750309

Kennedy, K. A. R. (1976). Human variation in space and time. Dubuque, IA: William C. Brown.

Kennedy, K. A. R. (1995). But professor, why teach race identification if races don't exist? American Journal of Forensic Sciences, 40, 796-800.

Kennedy, K. A. R. (2000). God-apes and fossil men: Palaeoanthropology of South Asia. Ann Arbor, MI: University of Michigan Press.

Knussman, H. R. von R. (1988). Biologie des menschen, ban 1, wissenschafts-Theorie, geschichte, morphologishe methoden. Stuttgart: Gustav Fisher Verlag.

Krogman, W. M., \& Sassaman, W. H. (1943). Skull found at Chanhudaro excavations. In E. J. H. Mackay (Ed.), Chanhu-daro excavations 1935-1936 (pp. 252-263). New Haven, CT: American Oriental Scoitey.

Lapique, L. (1905). Note sommaire sur une mission ethnologique dans le Sud de l'Inde: La race noire predravidienne. Bulletin de Museum d'Histoire Naturelle, 11, 283-285.

Lee, A., \& Pearson, K. (1901). A first study of the correlations of the human skull. Philosophical Transactions of the Royal Society, 196, 225-264. doi:10.1098/rsta.1901.0005 
Von Linnaeus, C. (1785). Systema naturae (10th ed.) London: Lackington and Allen.

Mackay, E. J. H. (1930-1934). Annual report of the archaeological survey of India 1930-1934.

Mackay, E. J. H. (1936). Excavations at Chanhu-daro by the American school of Indic and Iranian studies and museum of fine arts, Boston. Season 1935-1936. Bulletin of the Museum of Fine Arts, Boston, 34, 83-92.

Mackay, E. J. H. (1931). DK area. In J. Marshall (Ed.), Mohenjo-daro and the Indus civilization (pp. 233-261). London: Arthur Probsthain.

Mackay, E. J. H. (1943). Chanhu-daro excavations, 1935-1936. New Haven: American Oriental Society.

Majumdar, N. G. (1934). Explorations in sind: Being a report of the exploratory survey carried out during the years 1927-1928, 1929-1930, 1930-1931. Memoirs of the Archaeological Survey of India, 48.

Marshall, J. (1931). Mohenjo-daro and the Indus civilization, being an official account of archaeological excavations at Mohenjo-daro carried out by the government of India between the years 1922 and 1927. London: Arthur Probsthain.

Martin, R. (1928). Lehrbuch der anthropologie (2nd ed.) Jena: Fischer.

Mehra, K. L. (1963). Considerations of the African origin of Eleusine coracana (L.). Current Science, 32, 300-301.

Mery, W. (2000). Les ceramiques d'oman et l'asie moyenne: Une archeologii des exchanges a l'age du bronze. CRA Monographies 23. Paris: CNRS Editions.

Morant, G. M. (1922-1923). A first study of the Tibetan skull. Biometrika, 14, 193-260.

Oppenheim, A. L. (1954). Seafaring merchants of Ur. Journal of the American Oriental Society, 74, 6-17. doi:10.2307/595475

Piggott, S. (1846). The chronology of prehistoric north-west India. Ancient India, 1, 8-26.

Piggott, S. (1950). Prehistoric India. London: Penguin.

Possehl, G. L. (1986). African millets in South Asian prehistory. In J. Jacobson (Ed.) Studies in the archaeology of India and Pakistan (pp. 237-256). Delhi: Oxford and IBH and the American Institute of India Studies.

Possehl, G. L. (1996). Meluhha. In J. E. Reade (Ed.), The Indian Ocean in Antiquity (pp. 132-208). London: Kegan Paul International in As- sociation with the British Museum.

Possehl, G. L. (1997). Seafaring merchants of Meluhha. In B. Allchin (Ed.), South Asian archaeology (pp. 87-100). Delhi: Oxford and IBH.

Possehl, G. L. (1999). Indus age: The beginnings. Philadelphia, PA: University of Pennsylvania Press.

Possehl, G. L. (2002). The Indus civilization: A contemporary perspective. Walnut Creek, CA: Altamira Press.

Risley, H. (1908). The people of India. Calcutta: Thyaacker, Spink and Company.

Risley, H., \& Gait, E. A. (1903). Census of India 1901. Ethnographic Appendices 1. Calcutta and Simla: Government of India.

Ruff, C. (2002). Variations in human body size and shape. Annual Review of Anthropology, 31, 211-232. doi:10.1146/annurev.anthro.31.040402.085407

Sahni, D. R. (1926-1927). Mohenjo-daro. Annual Report of the Archaeological Survey of India 1926-1927:60-88.

Sauer, C. (1952). Agricultural origins and dispersals. New York: American Geographical Society.

Sauer, C. O. (1969). Seeds, spades, hearths and herds: The domestication of animals and foodstuffs. Cambridge, MA: MIT Press.

Shar, G. M., \& Vidale, M. (1985). Surface evidence of craft activity at Chanhu-daro. Annali dell'Instituto Universitario Orientale, 45, 585598.

Singh, P. (1970). Burial practices in ancient India: A study of eschatological beliefs of early man as revealed by archaeological sources. Veranasi: Prithivi Prakasha.

Thurston, E. (1909). Castes and tribes of central India. Madras: Government Press.

Todd, T. W. (1932). Preface. Punjab Gazetteer (Attock District) XXIX-A, 1930. Lahore: Government of India.

Vishnu-Mittre (1974). The beginnings of agriculture: Palaeobotanical evidence in India. In J. Hutchinson (Ed.), Evolutionary studies in world crops: Diversity and change in the Indian subcontinent (pp. 3-30). Cambridge: Cambridge University Press.

Wheeler, M. (1947). Harappa 1946: The defences and cemetery R37. Ancient India, 3, 58-130.

Wright, R. P. (2011). The ancient Indus: Urbanism, economy and society. Cambridge: University of Cambridge Press. 